\title{
ERECTILE DYSFUNCTION AND ASSOCIATED SOCIO-DEMOGRAPHIC FACTORS AMONG PATIENTS SUFFERING FROM ASTHMA
}

\author{
Omer Sultan, Muhammad Khalid, Muhammad Hammad Athar* \\ Pak Emirates Military Hospital/National University of Medical Sciences (NUMS) Rawalpindi Pakistan, *Combined Military Hospital Malir/ \\ National University of Medical Sciences (NUMS) Pakistan
}

\begin{abstract}
Objective: To determine the frequency of erectile dysfunction among the patients of asthma and analyze the associated socio demographic factors.

Study Design: Cross sectional study.

Place and Duration of Study: Department of Medicine, Pak Emirates Military Hospital Rawalpindi, from Oct to Dec 2018.

Methodology: One hundred and fifty seven patients of asthma diagnosed for more than one year by a consultant medical specialist or pulmonologist were included in the study. Erectile dysfunction was assessed by using the International Index of Erectile Function-5 (IIEF-5).

Results: Out of 157 patients of asthma, 74 (47.1\%) had no erectile dysfunction, 50 (31.8\%) had mild, 17 (10.8\%) had mild to moderate, $11(7.1 \%)$ had moderate and $5(3.2 \%)$ had severe erectile dysfunction. Mean age of the study participants was $41.74 \pm$ 3.16. Mean duration of asthma among the patients in this study was $5.98 \pm 4.38$ years. Poly-pharmacy and long duration of illness had significant association with erectile dysfunction ( $p$-value $<0.05)$.

Conclusion: There is a high frequency of erectile dysfunction among the patients suffering from asthma. Chronic illness when not under adequate control for a long time or is under control with poly pharmacy might give rise to problems which may be more troublesome than the primary illness.
\end{abstract}

Keywords: Asthma, Erectile dysfunction, Socio demographic factors.

This is an Open Access article distributed under the terms of the Creative Commons Attribution License (https://creativecommons.org/licenses/by-nc/4.0/), which permits unrestricted use, distribution, and reproduction in any medium, provided the original work is properly cited.

\section{INTRODUCTION}

Erectile dysfunction (ED) is a widely experienced problem and is defined as the inability to obtain and maintain an erection sufficient for satisfactory intercourse or other sexual expression. This problem has multiple dimensions and linked with significant distress and compromised quality of life ${ }^{1}$.

ED is a highly prevalent public health problem in both developing and developed countries ${ }^{1,2}$. ED is associated with or part of various medical conditions like heart disease ${ }^{3}$, type II diabetes mellitus ${ }^{4}$, chronic obstructive airway disease ${ }^{5}$, chronic kidney disease ${ }^{6}$, and rheumatoid arthritis ${ }^{7}$.

Asthma is a chronic disease which causes various changes in the oxygenation of tissues which affects the overall physiological well-being of the body ${ }^{8}$. Treatment of asthma also involves various agents which have been linked with sexual problems including the erectile dysfunction ${ }^{9}$. Therefore physiological and psychological effects of chronic illness and its medical treatment both predispose the individuals towards this problem which not only affect the individual but also to the partner and sometimes it is the partner who is in

Correspondence: Dr Omer Sultan, Department of Medicine, Pak Emirates Military Hospital Rawalpindi Pakistan

Received: 17 May 2019; revised received: 07 Jan 2021; accepted: 30 Jan 2021 greater distress ${ }^{1}$.

Literature of recent past has supported the association of asthma and erectile dysfunction among different populations of the world. A large nationwide study revealed that asthma has a strong association with erectile dysfunction and severity of asthma also determines the presence and severity of erectile dysfunction ${ }^{10}$.

Studies have been done in our setup regarding quality of life in asthma patients and knowledge of use of treatment modalitiesbut very limited work so far has been done on the sexual health status of these patients. Our study aimed to assess the presence and severity of erectile dysfunction among the patients of asthma and also analyze the socio-demographic factors related with erectile dysfunction in these patients.

\section{METHODOLOGY}

This cross sectional study was conducted at PakEmirates Military Hospital (PEMH) Rawalpindi, from October to December 2018. Sample size was calculated by using the WHO sample size calculator by using population proportion of $75 \%{ }^{11}$. Non probability consecutive sampling technique was applied to gather sample from the male patients of asthma reporting in the medical and pulmonology outpatient department. All the patients were male and between the ages of 25-55 years 
who had been suffering from asthma for at least one year and have given written informed consent were included in the study. Non consenting subjects and those with age $<25$ or $>55$ were excluded from the study. Patients with allergies secondary to identifiable causes and sexual problems before the diagnosis of asthma were not included in the study ${ }^{15}$. Patients with any other physical or psychiatric illness and illicit substance use were also excluded from the study. After the application of inclusion and exclusion criteria, 157 subjects were included in the final analysis.

Erectile dysfunction can be assessed by various standardized psychometric tools. International Index of Erectile Function (IIEF-5) is a commonly used instrument which we used in this study to record the presence and severity of ED. We applied validated version of this tool translated in urdu15. Scores of this tool have been interpreted as follows: 1 ) severe erectile dysfunction: IIEF-5 (1-7), 2) moderate erectile dysfunction: IIEF-5 (8-11), 3) mild-moderate erectile dysfunction: IIEF-5 (12-16), 4) mild erectile dysfunction: IIEF-5 (1721), 5) no erectile dysfunction: IIEF-5 (22-25).

After getting ethical approval from the hospital ethical review board committee and written informed consent form all the participants of this study IIEF-5 questionnaire was administered to the patients under the supervision of a health professional who translated or explained the questionnaire to those who had ambiguity in any point. Subjects were asked to answer the questions of the study tool according to their condition (IRB ltr dated 11 Sep 2018) regarding erectile function in last one month. Personal data and correlating factors such as age, education, smoking, poly-pharmacy and duration of illness were filled by the patient on a separate Performa attached to the IIEF- 5 questionnaire. Duration of illness was classed as disease lasting for less than or more than five years. Use of $>1$ drug for asthma was regarded as poly-pharmacy. Matriculation education was used as cut-off education for this study to classify the patients and look for the correlation. Confounding variables were identified and adjusted by detailed history taking, examination and review of all the old documents possessed by the patient.

Descriptive statistics were used to describe the characteristics of participants and the distribution of IIEF score. Variables in this study included age, education, smoking, poly-pharmacy and duration of illness. Between-group variances in categorical correlates were determined using chi-square. All statistical analysis was performed using Statistics Package for Social
Sciences version 24. Chi-square test was used and differences between groups were considered significant if $p$-values were $\leq 0.05$.

\section{RESULTS}

A total 172 patients of asthma were approached to participate in this study. All were age between 25-55 years. Five did not give consent for enrolment in the study. Ten were ineligible due to inclusion/exclusion criteria (3 were using illicit substance, 2 had clinical depression prior to diagnosis of asthma, 5 had comorbid DM). Thus, 157 patients of asthma were finally included in the study analysis. Out of these 157 patients of asthma, 74 (47.1\%) had no ED, 50 (31.8\%) had mild, 17 $(10.8 \%)$ had mild to moderate, $11(7.1 \%)$ had moderate and $05(3.2 \%)$ had severe ED. Mean age of the study participants was $41.74 \pm 3.16$. Mean duration of asthma among the patients in this study was $5.98 \pm 4.38$ years. Long duration of illness and poly-pharmacy had significant association with ED ( $p$-value 0.001 and 0.020) while all other factors studied were not found significantly associated in our study when chi-square was applied.

\section{DISCUSSION}

Chronic illnesses like DM, asthma, hypertension have a deleterious effect on the overall physiology of the body. All the biological functions of the body are affected in one way or the other. Sexual function is one of these, which not only affect the individual but also the partner living with him. Sometimes it is suffering of the partner with which the patient presents to the OPD. Around $50 \%$ of participants of our study showed some level of erectile dysfunction. No population based study has been available on patients of asthma regarding their sexual function in Pakistan however these results are in accordance with the studies done on similar subject in other parts of the world by kahraman et al, and chambers et al ${ }^{10,11,12}$. Results of our study show a true reflection of erectile problems in asthmatic patients of our set up as our study sample had no other diagnosed physical or mental illness. Important reason may be hypoxia or hypercapnia due to a chronic long standing lung illness ${ }^{17}$. Treatment options may pose additional risk to this problem ${ }^{18,19}$.

Erectile function of an individual has multidimensional basis. Physiological, neurological, endocrine and psychological factors affect this vital function of the body. Patient of long standing asthma can have one or more altered factors which may lead to this problem. Hypoxia and hypercapnia due to asthma as well as drugs used in asthma may cause impairment of erectile 
Table: Characteristics of the hypertension patients and theirinternational index of erectile function-5 score.

\begin{tabular}{|c|c|c|c|c|c|c|}
\hline $\begin{array}{l}\text { Socio } \\
\text { Demographic } \\
\text { Factors }\end{array}$ & $\begin{array}{l}\text { NoErectile } \\
\text { Dysfunction } \\
(22-25)\end{array}$ & $\begin{array}{c}\text { Mild } \\
\text { Erectile } \\
\text { Dysfunction } \\
(17-21)\end{array}$ & $\begin{array}{l}\text { Mild to Moderate } \\
\text { Erectile } \\
\text { Dysfunction } \\
(12-16)\end{array}$ & $\begin{array}{c}\text { Moderate } \\
\text { Erectile } \\
\text { Dysfunction } \\
(8-11)\end{array}$ & $\begin{array}{c}\text { Severe } \\
\text { Erectile } \\
\text { Dysfunction } \\
(1-7)\end{array}$ & $p$-value \\
\hline & \multicolumn{6}{|c|}{$\mathrm{n}(\%)$} \\
\hline Total & $74(47.1)$ & $50(31.8)$ & $17(10.8)$ & $11(7.1)$ & $05(3.2)$ & \\
\hline \multicolumn{7}{|l|}{ Age } \\
\hline $\begin{array}{l}25-40 \\
>40 \\
\end{array}$ & $\begin{array}{l}33(44.6 \%) \\
41(55.4 \%) \\
\end{array}$ & $\begin{array}{l}18(36 \%) \\
32(64 \%) \\
\end{array}$ & $\begin{array}{l}08(47.1 \%) \\
09(52.9 \%) \\
\end{array}$ & $\begin{array}{l}05(45.4 \%) \\
06(54.6 \%) \\
\end{array}$ & $\begin{array}{l}01(20 \%) \\
04(80 \%)\end{array}$ & 0.707 \\
\hline \multicolumn{7}{|l|}{ Education } \\
\hline $\begin{array}{l}\leq 10 \\
>10\end{array}$ & $\begin{array}{l}56(75.7 \%) \\
18(24.3 \%) \\
\end{array}$ & $\begin{array}{l}35(70 \%) \\
15(30 \%) \\
\end{array}$ & $\begin{array}{l}12(70.6 \%) \\
05(29.4 \%) \\
\end{array}$ & $\begin{array}{l}07(63.6 \%) \\
04(26.4 \%) \\
\end{array}$ & $\begin{array}{c}05(100 \%) \\
- \\
\end{array}$ & 0.386 \\
\hline \multicolumn{7}{|c|}{ Duration of Illness } \\
\hline $\begin{array}{l}<5 \text { years } \\
>5 \text { years }\end{array}$ & $\begin{array}{c}70(94.7 \%) \\
04(5.3 \%) \\
\end{array}$ & $\begin{array}{l}36(72 \%) \\
14(28 \%) \\
\end{array}$ & $\begin{array}{l}15(88.2 \%) \\
02(11.8 \%) \\
\end{array}$ & $\begin{array}{l}07(63.6 \%) \\
04(36.4 \%) \\
\end{array}$ & $\begin{array}{l}02(40 \%) \\
03(60 \%) \\
\end{array}$ & $<0.001$ \\
\hline \multicolumn{7}{|c|}{ Tobacco Smoking } \\
\hline $\begin{array}{l}\text { Non smoker } \\
\text { Smoker }\end{array}$ & $\begin{array}{l}34(45.9 \%) \\
40(54.1 \%) \\
\end{array}$ & $\begin{array}{l}19(38 \%) \\
31(62 \%) \\
\end{array}$ & $\begin{array}{l}06(35.3 \%) \\
11(64.7 \%) \\
\end{array}$ & $\begin{array}{l}04(36.4 \%) \\
07(63.6 \%) \\
\end{array}$ & $\begin{array}{l}03(60 \%) \\
02(40 \%) \\
\end{array}$ & 0.750 \\
\hline \multicolumn{7}{|l|}{ Poly-Pharmacy } \\
\hline $\begin{array}{l}\text { No } \\
\text { Yes } \\
\end{array}$ & $\begin{array}{l}37(50 \%) \\
37(50 \%) \\
\end{array}$ & $\begin{array}{l}13(26 \%) \\
37(74 \%) \\
\end{array}$ & $\begin{array}{l}06(35.3 \%) \\
11(64.7 \%) \\
\end{array}$ & $\begin{array}{l}05(45.4 \%) \\
06(54.6 \%) \\
\end{array}$ & $\begin{array}{l}01(20 \%) \\
04(80 \%)\end{array}$ & 0.074 \\
\hline
\end{tabular}

function in the patients suffering from asthmatic illness ${ }^{17}$.

Increasing age was not a significant correlate with erectile dysfunction in our study. Different results have been reported in various studies done in other parts of the world and $p$-value in few studies was $>0.05$ showing that no significant relationship of increasing age with ED and others had $p$-value $<0.05$ showing significant association of advancing age with presence of $\mathrm{ED}^{11,12,20}$. There is a gradual decline in erectile function with aging in healthy individuals as well. Range of age of our sample population was small and we did not include patients of asthma above fifty five years of age, which might be reason for our results.

Long duration of illness was strongly related to presence and severity of erectile dysfunction in our study. It is in accordance with the existing literature and studies done by Kaharaman et al and Susto et al11,12. Most chronic illnesses cause problems related to sexual health specially those involving metabolic, electrolyte or hypoxic changes. Asthma looks no exception to this as shown by our study as well as other studies worldwide done in 2013 and 2016.

Polypharmacy is a problem which brings a lot of risks with it. It may be linked with good disease control but may be at the cost of various side effects. Polypharmacy may be reflection of poor disease control and long standing illness. Results of our analysis revealed that polypharmacy is associated with increased presence and severity of erectile dysfunction. It is also in accordance with the studies done in west on this subject especially study done by Malik et al, in which $p$-value $<0,05$ showing poly pharmacy had a statically significant relationship with presence of $\mathrm{E}^{12,14}$.

\section{LIMITATION OF STUDY}

Randomized selection of study subjects from all the asthmatic patients from all over the country was not done. Therefore, the results of the present study cannot be generalized. Cross-sectional study design was used which cannot confirm the cause and effect relationship between the variables.

Methodological issues also arise with the use of self-administered tool to detect the presence and severity of erectile dysfunction as patients may have a chance to under or over report the symptoms. Thus larger studies with more sophisticated study design should be performed in future with a large sample size in order to generalize the results.

\section{CONCLUSION}

There is a high prevalence of erectile dysfunction among the patients suffering from asthma. Chronic illness when not under adequate control for a long time or is under control with poly pharmacy may give rise to problems which may be more worrisome than the primary illness.

\section{CONFLICT OF INTEREST}

This study has no conflict of interest to be declared by any author. 


\section{REFERENCES}

1. Wang W, Fan J, Huang G, Zhu X, Tian Y, Tan H, et al. Metaanalysis of prevalence of erectile dysfunction in mainland China: evidence based on epidemiological surveys. Sex Med 2017; 5(1): e19-e30.

2. Zubair UB, Mumtaz H, Tabassum AS. Effect of high altitude on erectile function in otherwise healthy individuals. Pak Armed Forces Med J 2016; 66(3): 314-18.

3. Chaudhary RK, Shamsi BH, Chen H, Tan T, Tang K, Xing J. Risk factors for erectile dysfunction in patients with cardiovascular disease. J Inter Med Res 2016; 44(3): 718-27.

4. Seid A, Gerensea H, Tarko S, Zenebe Y, Mezemir R. Prevalence and determinants of erectile dysfunction among diabetic patients attending in hospitals of central and northwestern zone of Tigray, northern Ethiopia: a cross-sectional study. BMC Endocr Disord 2017; 17(1): 16-20.

5. Scullion JE, Vincent E. Erectile dysfunction in COPD: A hidden co-morbidity. Chron Respir Dis 2016; 13(1): 3-4.

6. Edey MM. Male sexual dysfunction and chronic kidney disease. Front Med (Lausanne) 2017; 4(1): 32-38.

7. Dorner TE, Berner C, Haider S, Grabovac I, Lamprecht T, Fenzl $\mathrm{KH}$, et al. Sexual health in patients with rheumatoid arthritis and the association between physical fitness and sexual function: a cross-sectional study. Rheumatol Int 2018; 38(6): 1103-14.

8. Collins J-A, Rudenski A, Gibson J, Howard L, O'Driscoll R. Relating oxygen partial pressure, saturation and content: the haemoglobin-oxygen dissociation curve. Breathe 2015; 11(3): 194-201.

9. Conaglen HM, Conaglen JV. Drug-induced sexual dysfunction in men and women. Aust Prescr 2013; 36(2): 42-45.

10. Chou KT, Huang CC, Chen YM, Perng DW, Chao HS, Chan $\mathrm{WL}$, et al. Asthma and risk of erectile dysfunction--a nationwide population-based study. J Sex Med 2011; 8(6): 1754-60.
11. Kahraman H, Sen B, Koksal N, Kilinç M, Resim S. Erectile dysfunction and sex hormone changes in chronic obstructive pulmonary disease patients. Multidiscip Respir Med 2013; 8(1): 66-70.

12. Soto Campos JG, Rojas Villegas J, Padilla Galo A, Marina Malanda N, Garcia Rivero JL, Pinedo Sierra C, et al. Grupo Emergente de Asma (GEA) del Área de Asma de la SEPAR. Impact of Asthma on the Sexual Functioning of Patients. A CaseControl Study. Arch Bronconeumol 2017; 53(12): 667-74.

13. Chambers SK, Chung E, Wittert G, Hyde MK. Erectile dysfunction, masculinity, and psychosocial outcomes: a review of the experiences of men after prostate cancer treatment. TranslAndrol Urol 2017; 6(1): 60-68.

14. Malik M, Khan A, Hussain A, Hashmi A. Assessment of Healthrelated Quality of Life Among Asthmatic Patients: The Need for Structured Pharmaceutical Care Delivery System in Pakistan. J Pharm Bioallied Sci 2017; 9(4): 272-78.

15. Athar $\mathrm{MH}, \mathrm{Zubair}$ UB. Impact of proper metered dose inhaler technique over peak expiratory flow rate in moderate persistent bronchial asthma. Pak Arm For Med J 2018; 68(4): 975-79.

16. Mahmood MA, Rehman KU, Khan MA, Sultan T. Translation, cross-cultural adaptation, and psychometric validation of the 5item International Index of Erectile Function (IIEF-5) into Urdu. J Sex Med 2012; 9(7): 1883-86.

17. Ollivier JE. Asthma and impotence. The story of an unexpected connection. JAAPA 2000; 13(6): 59-62.

18. Geddes DM. Inhaled corticosteroids: benefits and risks. Thorax 1992; 47(6): 404-07.

19. Kirmaz C, Aydemir O, Bayrak P, Yuksel H, Ozenturk O, Degirmenci S. Sexual dysfunction in patients with allergic rhinoconjunctivitis. Ann Allergy Asthma Immunol 2005; 95(6): 525-29.

20. Tai SY, Wang LF, Tai CF, Huang YT, Chien CY. Chronic rhinosinusitis associated with erectile dysfunction: a population-based study. Sci Rep 2016; 6(1): 32195-98. 